\title{
Disaster Vulnerability, Severity of Flood Losses and Information Dissemination In Ogbaru Local Government Area of Anambra State, Nigeria
}

\author{
Dr. Augustina U. Okonkwo, and Rita U. Onyeizugbe.
}

\begin{abstract}
Ecological problem of coastal flooding is one of the many challenges of riverine areas of Eastern Nigeria. The 2012 incident of river overflow was rather alarming. Part of the problem is with means of creating awareness and information about impending flood forecasts as well as convincing people who are attached to the environment to relocate to dry areas. This paper, therefore, examined the environmental effects of 2012 flooding in Ogbaru LGA of Anambra State, investigating the role of information dissemination in the severity of flood losses. It also considered flood disaster vulnerability in the study area. Field survey and questionnaire administration were used for data collection in this study. Stratified sampling method was used for questionnaire administration. Z-test was adopted in testing the hypothesis that information dissemination is not contributory to severity of flood losses during 2012 flooding in Ogbaru LGA. The study revealed that warnings and information dissemination concerning the impending 2012 flooding were not properly done and media used for such warning were not available to the local populace. It was also discovered that the poor and ethnically attached individuals are more vulnerable to flood disaster in the area. The paper recommended among other things that information / awareness about future flooding should be brought to the people using means and media available to the local populace. Serious education and awareness campaign should be undertaken to convince the ethnically attached in the community to relocate to other places to avoid becoming victims. The government should concentrate more on these measures that would prevent losses than on relief distribution after the losses.
\end{abstract}

Keywords: Disaster, Flood losses, Information, Severity, Vulnerability.

\section{INTRODUCTION}

$\mathrm{V}$ ARIOUS forms environmental problems among which are flooding, soil erosion, drought and desertification, pollution, ozone depletion, waste management etc, abound all over the world. Floods are among the most devastating natural disasters in the world claiming more lives and causing more property damage than any other natural phenomena [1].

Augustina U. Okonkwo (Ph.D) 1, Department of Environmental Management, Chukwuemeka Odumegwu Ojukwu University, Uli-Campus. Anambra State, Nigeria. e-mail: auokonkwo@yahoo.com

Rita U. Onyeizugbe2 is with the Physical Planning Unit, Nnamdi Azikiwe University, Awka, Anambra State, Nigeria
Flooding is a situation that results when land that is usually dry is covered with water. It may be as a result of river overflowing its banks due to heavy/ prolonged rainfall. It can occur due to collapse of a dam or when it is overfilled. Flooding occurs naturally on flood plains and endangers whosever refuses to prepare for its occurrence. Flood events may be predicted but at times it happens without warning. Flooding can be extreme weather event naturally caused by rising global temperature which results in heavy down pour, thermal expansion of the ocean and glacier melt, which in turn result in rise in sea level, thereby causing salt water to inundate coastal land. Described by [2], as the most common of all environmental hazards, flood regularly claims over 20,000 lives per year and adversely affects around 75 million people worldwide. According to [3], flood causes one third of all deaths, one third of all injuries and one third of all damages from natural disasters. Among the records of global flood incidents are Pittsburgh,1936; Manitoba, 1997; Bangladesh, 2009; Red river in Winnipeg, 2009; Snoqualmie,2009 etc [4].

In Nigeria and other African countries the pattern is similar with the rest of the world. Memorably is the popular Ogunpa flooding of 1980, the yearly flooding of many parts of Lagos State, 2010 flooding of Kengana in Sokoto State, 1999 and 2001 of Yenogoa in Bayelsa State, 1988 and 2001 of Kano State and 2012 flooding of so many communities in the coastal states of Nigeria. Flood incidents in Nigeria forced millions of people to flee their homes, destroyed businesses, polluted water sources and increased risk of diseases [5]; [6]; [7]; [8]; [9]. The flooding of 2012 has devastating effect on many Riverine communities in various States of Nigeria and Ogbaru Local Government Area happens to be one of them. The catastrophe of 2012 was attributed to excessive and prolonged rainfall of that year which resulted in the failure of dams, particularly, Lagdo dam in Cameroun. The overfilled dam released excess water to River Niger and River Benue in Nigeria resulting in these Rivers overflowing their Banks. This resulted also in flooding of communities along or close to these Rivers. However, the 2012 flood was predicted and warnings issued for communities in the flood prone areas to relocate to dry areas yet the severity of losses recorded were rather 
alarming and devastating. This study is undertaken, therefore to find out how far the warnings were related to the concerned people and to determine those who are most vulnerable to flood incidents in the study area. The rest of the paper is organized as follows; study area, theoretical and conceptual framework, methodology,

findings, implications $\backslash$ recommendations and conclusions.

\section{II.STUDY AREA}

Ogbaru Local Government is one of the 21 Local Government Areas that make up Anambra State in Nigeria. It is located between latitudes $5^{\circ} 42^{\prime} \mathrm{N}$ and $6^{\circ} \quad 08^{\prime} \mathrm{N}$ and Longitudes $6^{\circ} 42^{\prime} \mathrm{E}$ and $6^{\circ} 50^{\prime} \mathrm{E}$. The study area is bounded to the North by Onitsha and Idemili Local Government areas, to the South Imo, and Rivers States; to the East by Ekwusigo and Ihala Local Government Areas and to the West by the River Niger and Delta State (Fig 1

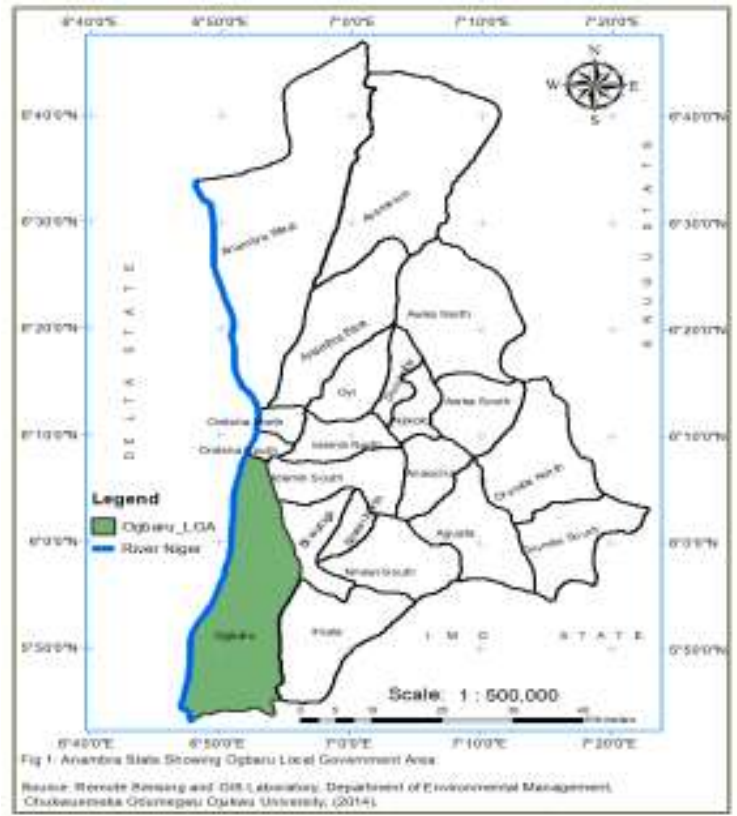

Fig. 1: Anambra State Showing Ogbaru Local Government Area.

The average climatic conditions are wet season from March to October and dry season from November to February. The highest recorded rainfall is from June to September. The average annual rainfall ranges from $2000 \mathrm{~mm}$ to $3000 \mathrm{~mm}$. It has a mean daily annual temperature of $30^{\circ} \mathrm{C}$ and $27^{\circ} \mathrm{C}$ respectively. The average relative humidity ranges between $60 \%-70 \%$ in January and $80 \%-90 \%$ in July [10].

Ogbaru floods during the rainy season and dries up during the dry season, though the flood lasts for a long time before receding. The flooding is as a result of the low and flat topography with slope angles of $1^{\circ}-3^{\circ}$. Thus, some of the communities are flooded for over 8 months in a year.

The relief is a plain land of heights ranging between $0-1 \mathrm{~m}$ and characterized by swampy conditions due to its alluvial mud content. It has two major Rivers; River Niger and Ulasi River which is the major tributary, though there are local creeks and ponds all over its landscape. The water table of the aquifer is quite shallow with average elevation of $25 \mathrm{~m}$ above sea level. The vegetation is a mixture of fringing forests along the banks of the River Niger and Guinea Savannah in the hinterland. According to the 2006 National census, the LGA has a population of 221,879 . The towns that make up the local government include: Atani (the head quarter), Akili-Ogidi, Akili Ozozor, Amiyi, Mputu, Obaogwe-ohita, Odekpe, Ogbakuba, Ochuche, Umuzu, Okpoko and Ogwuikpele (Fig 2).

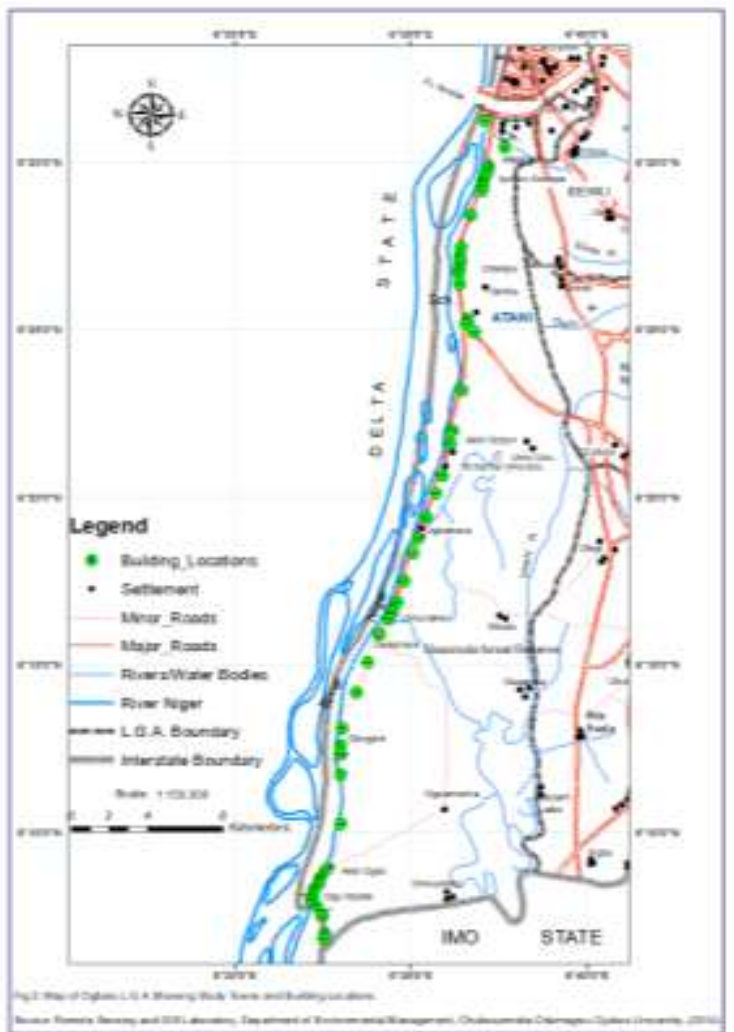

Fig. 2: Map of Ogbaru L.G.A. Showing Towns and Building Locations.

\section{THEORETICAL AND CONCEPTUAL FRAMEWORKS.}

In this study two frameworks; theoretical and conceptual were employed. For the theoretical framework systems theory was adopted. It is termed " Over Flow System in Ogbaru'. [11], defined a system as the entity composed of a number of parts, the relationship between these parts and the attributes of both the parts are the relationship. The systems theory has the advantage of considering the performance of a phenomenon. The subsystems are conceptualized as physical and human subsystems. The physical subsystem consists of water resource, lithology and climate. While the human subsystem consists of land use, population and public awareness. The physical subsystem is resolved into climate, that is the length and intensity of the rainy season; water resource referring to the presence of water bodies and water content of the soil; and lithology implying the low lying land (flat terrain) coastal area. 
The human subsystem includes the degree of human interference involving such activities like agricultural practices, industrial activities, residential settlement and population factors. Also under human subsystem is the issue of public awareness which includes the fact of impending flooding.

The Conceptual Framework, on the other hand, is concerned with human adjustment and avoidance. This was based on a dissertation by Gilbert White in 1942 which was published as a book in 1945 titled " Human Adjustment to Floods" [12]. The work caused a shift in the paradigm of flood plain management in the United States. He was of the opinion that the four basic elements of flood problem are; the flood hazard, the environmental features of the flood plain, the human occupancy of the flood plain and the adjustment of human occupancy to flood hazard. The major objective of Whites research was to identify and examine the range of possible adjustments to flood plain. He observed that the major factors affecting adjustment to flood hazard include the severity of damages, benefits from natural resources derived from the flood plain, location benefits, institutional inertia etc.

Robert Kates, a student of Gilbert White, supporting the researcher, observed that the theory of human environment has shifted from focusing solely on the physical aspects, to the relationships between humans and their environment [13]. Summarizing, White argued that rather than trying to control flood with leeves and reservoirs, society might find it more effective to avoid developing flood plains or find more productive use such as recreational areas. According to him "floods" are act of god, but flood losses are largely acts of man.

The conceptual framework is suitable for this work since lithology is one of the attributes of the physical subsystem of the "Over flow System in Ogabru', The low lying nature of the land is a s serious factor of flooding in the area. Therefore, flood losses can be avoided by human adjustment to the flood plain.

\section{METHODOLOGY OF STUDY}

The study was done using field observation, personal interview and questionnaires for realization of data in 600 households in the study area. The head, Town Planning Unit and head, Administration of Ogbaru Local Government Area were interviewed to ascertain their views on human activities, effects of flooding in the area, the possibility of relocating settlers from the flood prone areas. Stratified sampling method was used to determine the population to be studied in each of the 16 communities in the Local Government Area. Then using purposive sampling method questionnaires were administered to 600 households who were affected by the 2012 flooding. The questionnaire, among other things gathered information on the respondents' awareness of the impending 2012 flooding, the severity of flood losses, and vulnerability to flood losses.

A Z-test analysis was performed on the respondents' access to information concerning the prediction of the 2012 flooding.
This was to evaluate the hypothesis that information is not contributory to the severity of losses during 2012 flooding in Ogbaru.

\section{FINDINGS}

\section{A. Flood Loses}

The most devastating effects of 2012 flooding in Ogbaru Local Government are the damage to infrastructure, crops and water quality. Roads and footpaths were submerged making movement impossible. Even 6 months after the floods receded, debris and silt deposits were seen covering the roads. Electricity transformers were submerged and destroyed; electric poles were pulled down, affecting power supply in the area up to one year after the incident. Buildings were submerged which resulted in occupants being trapped, or displaced. While some occupants relocated to stay with relatives or in displaced people's camps, others stayed back to live under harsh human conditions (Plate 1, 2 and 3). Factories and other minor industries were not spared thereby putting a halt to economic activities.

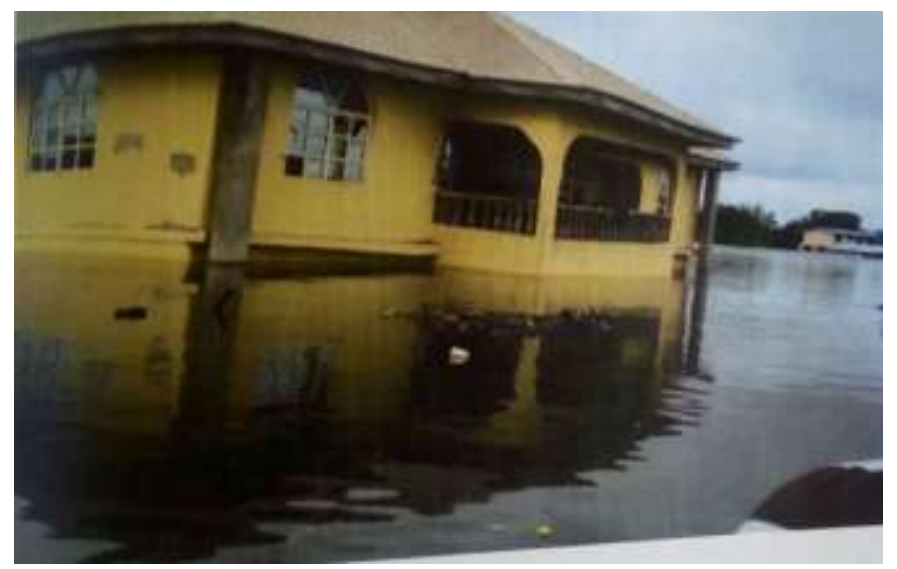

Plate 1: Showing submerged Buildings

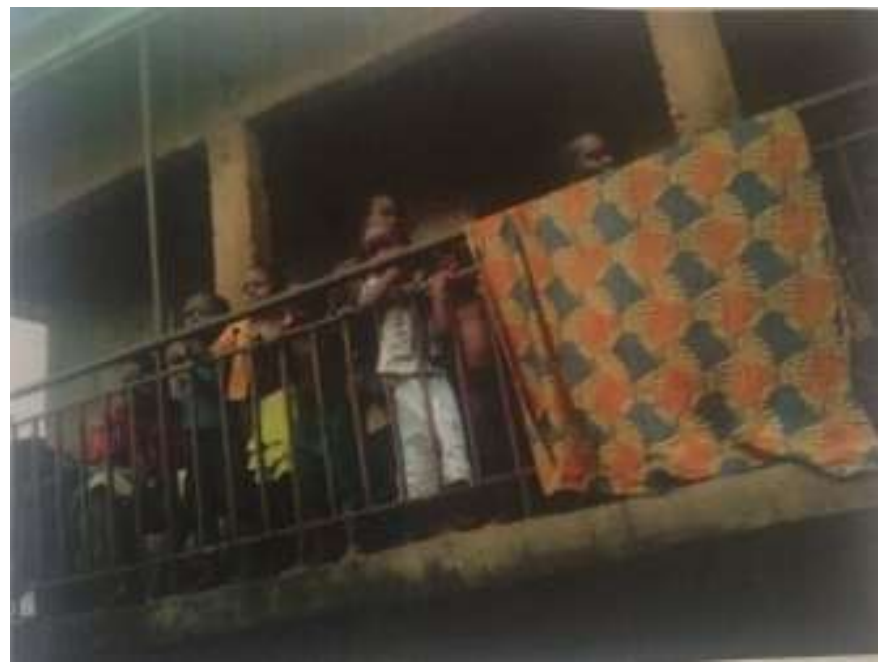

Plate 2: Showing occupants being trapped after a heavy flooding 


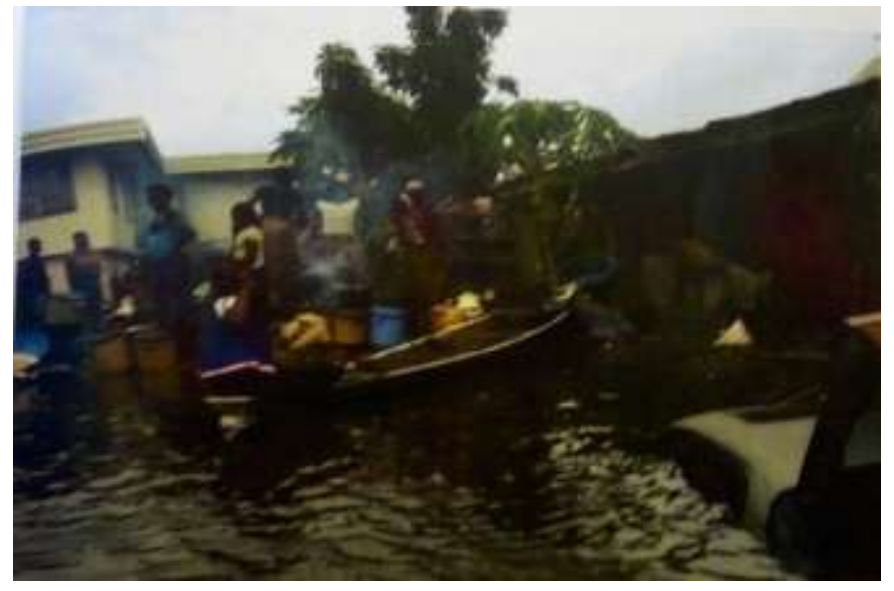

Plate 3: Showing people living under harsh human conditions due to effects of flooding.

\section{B. Information Flood Warning}

It was reported that the 2012 flooding was predicted by the Nigerian Meteorological Agency (NIMET) in March 2012 and that warning was subsequently issued out through the Nigerian television Authority (NTA). The warning was purposely aired during the 9.00am Network News on the 26th and 27th March 2012. Investigation revealed that television reception is almost nil in this area. Majority of the populace are low income and farmers. Power supply is generally poor except for few who can afford small generating sets.

The research revealed that $82.7 \%$ of the respondents did not hear the announcement and warning. It implies that only $17 \%$ of the respondents were aware of the warning. All the approximately $83 \%$ of the respondents who were not aware of the warning responded that they would have relocated if they knew about the forecast and warning.

The research further revealed that medium available to the majority in the area is radio. The effective modes of information dissemination in area are town criers, the church, community meetings and age grades.

\section{Vulnerability to Flood Loses}

Approximately $17 \%$ of the respondents were aware of the flood warning and yet were caught up with it because they refused to relocate earlier. Responding to the reasons for not relocating, $47 \%$ was due to poverty and helplessness, while 53\% complained about ethnicity and attachment to the land and environment of Ogbaru. For them there is no envisaged possibility of survival else were, if not in their community. These people have been experiencing flooding and yet never considered relocation and resettlement as an option.

\section{D.Hypothesis Testing}

A z-test analysis was performed to evaluate the hypothesis that information is not contributory to severity of losses during the 2012 flooding in Ogbaru. At 0.05 level of significance, with $\mathrm{P}$ value of 0.83 , the null hypothesis was rejected, thus accepting the alternative that information contributed to the severity of losses during the 2012 flooding in Ogbaru.

\section{IMPLICATIONS $\backslash$ RECOMMENDATIONS}

The findings of this study demand that efforts should be geared towards risk mitigation. The flood affected land use, infrastructure, and crops, means of livelihood and general comfort and existence of the people.

Though the magnitude and intensity of 2012 flood was anticipated and warnings issued by the appropriate agency, it did not get to the people who were mostly concerned. The simple reasoning being that the means used was not appropriate and available to the concerned.

The most vulnerable people to flood losses in the study area are still uninformed. Though coastal flooding frequently occur in this area, the poor and ethnically attached, do not still consider relocation or resettlement as an option because of lack of proper education and conviction.

This paper is therefore recommending that the conceptual framework of "Human Adjustment to Flood" by White (1945) be adhered to as a remedy to risk mitigation in the study area. In order works, it is better to avoid developing the flood plain into human settlement but rather put it into such uses as recreational purposes and the likes.

It is important that disaster alerts and warnings should be made available to the people through variety of media not just the television. Efforts must be made to find out the most effective means of information dissemination available at the grass root level and to the local populace and use same to get information to them.

The government, at all levels, should take up serious education and awareness campaigns to the grass root, especially, the disaster prone areas. It requires using every possible means to convince the poor and ethnically attached group to accept relocation and resettlement as the best option as well as providing them with means and necessary facilities. By so doing they will be provided with an enabling environment to move on with their lives.

\section{CONCLUSION}

The foregoing recommendations would go a long way to foster disaster risk and losses mitigation. The government should concentrate more on these measures that would avert severity of losses than in the rudimentary relief distribution after every flood event and losses that makes the circle continue to repeat itself.

\section{REFERENCES}

[1] A.E. Kesiena, The Devastating Effect of Flooding in Nigeria, 2012, wwwfloodingnigeria.com. Accessed 3/11/13.

[2] K. Smith, Risk Assessment and Disaster Management in Environmental Hazards: Assessing Risk and Reducing Disaster, Routledge, 1996, Chap3; 55-80.

[3] P.E. Askew, Causes and Devastating Effects of Flooding: A National Review of Disaster/Risk reduction; Ibadan, Intect Publisher Limited, 1999. 
[4] A.K. Etuonovbe, The Devastating Effect of Flood in Nigeria, 2012, wwwwikipediafreeencyclopedia,com. Accessed January 2013.

[5] E. Baiye, Human in the Throes of Floods: The Guardian Thursday October 8, 1988, P.9.

[6] T. Akinyemi, Stemming the Tide of Lagos Floods; The Guardian, Friday July 20, 1990, P.7.

[7] C. Nwabuani, Ogunpa River leaves bitter after Taste in Tragic Course through Abeokuta: The Guardian, October 21, 1991, P.9.

[8] NEST, Nigerians Threatened Environment, a National Profile. Ibadan; Intec Printers LTD, 1991.

[9] R Edward-Adebiyi,. The Story of Ogunpa: The Guardian Saturday, May 17, 1997, P.5.

[10] A.E. Onyido, V.O. Ebonighe, N.A. Ozumba, O.O. ikpeze, M.O.Obiukwu and E.S. Amadi, An Investigation of the Methods of Self Protection Against Mosquito Bites in Ogbaru L.G.A. of Anambra State, Nigeria: new York Science Journal.Vol.4, no.8, 2011.

[11] G.I. Immegart and F.J. Pilecki, An Introduction to System for the Educational Administrative Reading: Addision- Wesley Publishing Co PP.1-72, 1973 .

[12] G.F. Whites, Human Adjustment to Flood, University of Chicago, Department of Geography Research Paper No, 29, 1945.

[13] R. Kates, The Human Environment: The Road not Taken, the Road still Beckoning. Annuals of the Association of American Geographers. Vol. 77, no.4, PP. 525-354, 1987. 